\title{
Artificial Intelligence and Its Use in Financial Markets
}

\author{
Lilia Mirgaziyanovna Yusupova ${ }^{1}$, Irina Arkadevna Kodolova ${ }^{1}$, Tatyana Viktorovna Nikonova ${ }^{1}$, Madina Irekovna \\ Agliullina $^{1} \&$ Zarina Irekovna Agliullina ${ }^{1}$ \\ ${ }^{1}$ Institute of Management, Economics and Finance, Kazan Federal University, Russia \\ Correspondence: Lilia Mirgaziyanovna Yusupova, Associate Professor, Department of Financial Markets and \\ Financial Institutions, Institute of Management, Economics and Finance, Kazan Federal University, Russia. E-mail: \\ Lili2407@.list.ru
}

Received: August 2, 2020

Accepted: September 15, 2020

Online Published: October 4, 2020

doi:10.5430/ijfr.v11n5p353

URL: https://doi.org/10.5430/ijfr.v11n5p353

\begin{abstract}
The global financial system is currently at a new stage of its development, which is characterized by the introduction of information and communication technologies in all financial spheres. They allow improving business processes and company management and the process of providing services, as they enable organizations to receive more information about their customers and consumers, therefore, to provide better financial services that meet the requirements of customers.In the process of digitalization of the economy, a large role is played by banking organizations. In the conditions of increased competition in the market, banks are forced to continually improve their activities and introduce the most advanced technologies for carrying out business processes and working with clients. One of the most state-of-the-art technologies is artificial intelligence and Big Data. This technology is a combination of technologies targeted at processing vast amounts of data, and the ability to process fast incoming data in large volumes.
\end{abstract}

Keywords: digital financial services, artificial intelligence, digital banking services, online banking, digital banking, internet banking, remote service

\section{Introduction}

One of the most significant trends in the global economic development that affects the development of the banking sector is the digitalization of the economy. These changes are associated with the widespread adoption of technologies that fit into a completely new concept of digitalization. The digitalization processes involve most countries of the world and areas of activity, including the economic sphere. In a narrow sense, digitalization is "the conversion of information into digital form, which in most cases leads to lower costs, the emergence of new opportunities, etc." (Shal, 2017) A large number of such transformations entail the use of the term "digitalization" in its broad sense.

As already noted, digitalization also affects the banking sector, and as a result of their interaction, "digital banking" is obtained. It is understood as a completely new approach in the interaction of banking institutions and their customers, which embraces innovations in the sphere of financial services in the field of digital and information technologies.

In recent decades, the technology of banking operations has changed significantly, more and more banking operations are carried out through remote banking systems (remote banking services). There are neobanks (online-banks) - banks without offices, personnel and paper documents circulation. In the banking sector, artificial intelligence technologies are beginning to be applied.

\section{Methods}

The methodology of the study is based on the application of classical scientific methods and techniques, namely: systematic consideration of the object and subject of the study, dialectical logic, analysis and synthesis, methods of grouping, comparison, generalization, which allows speaking about the complexity, integrity, and reliability of the results of the study.

Artificial intelligence (AI) technologies and their applications in the financial market play an essential role in the digital economy (Ahmadi \& Movahed, 2019). Until recently, the proper consideration was not given to the analysis and visualization of data. However, the need to solve this problem has started to increase.

Thus, the industries, enterprises, organizations and companies in the management system can receive and visualize data from different sources, systematize and solve analytical problems. This opportunity allows having an adequate 
idea of what is happening in real time, identify new trends, track the actions of customers, partners and consumers and be ready to make more correct management decisions.

The solution of the analytical tasks necessary for making management decisions could be observed, for example, in PAO Rosbank. Here the Location Intelligence Technology is used (hereinafter LI), which is implemented in the Atlas geographic information system to manage the branch network.

LI technology aggregates the data of all branches and divisions of the bank, gives a comparative analysis, calculates the effectiveness and potential, based on data of the activity of customers, competing banks, population and other statistical information.

The application of advanced technologies allows maintaining a high development speed and using a scientific approach to improve the effectiveness of the management network. With the help of geodata and predicted models, optimal decisions are made with certain accuracy.

The main technologies of LI are the interactivity of reporting systems, their visualization with high-quality processing of the necessary data. Thus, in order to analyze the distribution of expenses in the bank during the last quarter, the area of interest is needed to be selected on the map, based on which the selected criteria of LI technology will be able to accurately extract the necessary information in the context of cost types, with the specification of the time of expenses.

Such data should be tailored to the reporting system. And for ease of use, the received report can be exported in a convenient format, for example, in Excel. LI technology has several applications used to solve the following problems:

- $\quad$ analysis of the information about potential consumers;

- $\quad$ establishing a connection between location and the operational data;

- $\quad$ accumulation of data from various sources;

- $\quad$ analysis of the relationships between objects located in different territories;

- $\quad$ selection of optimal solutions.

LI platforms typically use dashboards with a cartographic base, complemented by enterprise mashup technologies. They are most convenient for combining the presentation of geographical, relevant and business information. (Neznamov, 2018)

At the beginning of 2018, the general meeting of the FinTech Association decided to develop the direction "Research on Big Data Technologies and Artificial Intelligence in the Areas of Their Application in the Financial Market".

The opening of this direction plays a huge role in the development of the digital economy of our government. In this case, subject experience is used in processing big data and implementing the latest AI technological solutions. Their goal is to create a huge integrated center for the development of digital competencies within the Association. (Yusupova et al., 2018 \& Bodrov et al., 2018)

In the course of this goal, the tasks of creating cases based on the extensive collected data will be solved. Sberbank of Russia, for example, plans and even seeks to introduce artificial intelligence in almost every process of the bank and plans to extend this technology to all areas of this business, Figure 1.

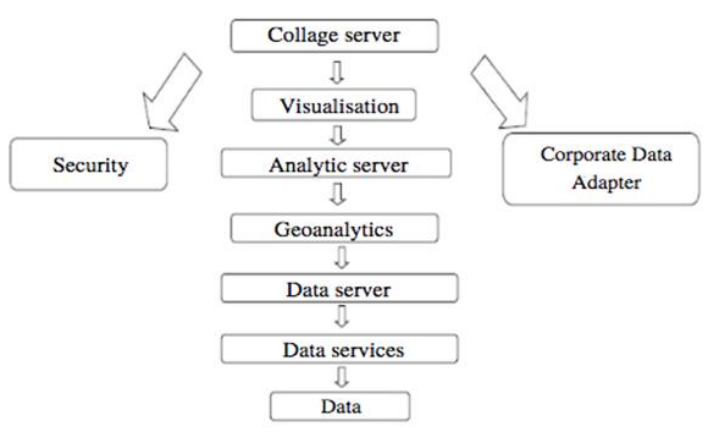

Figure 1. Location intelligence platform architecture 
The Binbank's project uses new approaches, for example, the construction of an uplift model that predicts the reaction of each client to certain specific actions. This also provides an opportunity to modernize and improve processes without any unforeseen incidents in the system and allows you to determine the most modernized option for interaction with each borrower.

Using such a model, the bank releases resources and directs them to the necessary communications with customers, thereby significantly increasing the efficiency of work with overdue debts. Costs are reduced, borrower discipline is improved, and efficiency is increased. Table 1 demonstrates the classification of banks by the level of use of AI technologies (Artificial Intelligence in the Banking Secto, 2018).

Table 1. Classification of banks by the level of AI technology use

\begin{tabular}{ll}
\hline Brief description of use & Banks \\
\hline Significantly above average & Tinkoff Bank, Gazprombank (AO), MTS Bank (PAO) \\
\hline Above average & $\begin{array}{l}\text { Credit bank of Moscow (PAO), Russian Standard Bank (AO), } \\
\text { Promsvyazbank (PAO), CB Renaissance Credit (OOO) }\end{array}$ \\
\hline Close to average & $\begin{array}{l}\text { The Ural Bank for Reconstruction and Development" (PAO), BCS } \\
\text { Bank (AO), Bank Otkritie Financial Corporation (PAO) }\end{array}$ \\
\hline
\end{tabular}

The usage of AI gives tremendous opportunities and perspectives in the banking sphere. Such a trend should be fixed in the modern economy in the field of customer service. Many banks are actively implementing and have already implemented AI-based applications that answer questions such as "how much is spent on products, what is the loan debt and when to pay it off and much more." There are also applications of bills analysis by the payment system, for example, for mobile communications, the Internet and offer the owner the most favorable rates and services.( MirgaziyanovnaYusupova et al., 2019 \& Kodolova et al., 2019)

As we can see, the field for using AI is vast, it is developing and claims deeper studying in modern world trends. Over the nearest 5 years, the qualitative development of banking service will occur due to the implementation of processing and data analysis systems. AI in the financial sector and its technologies are perspectives both in the external and domestic markets. On the one hand, it helps to get extra profit and provides better service for clients and saving time of bank clients.

Technologies of Big Data are implemented in many fields of the financial sphere - from targeted mobile marketing to identifying signs of fraud and from managing money to attracting customers, Figure 2. (The law on artificial intelligence will appear in Russia \& Thomson Reuters: Big data matured 30 years ago in finance \& How FinTech Uses Big Data - Textbook Examples)

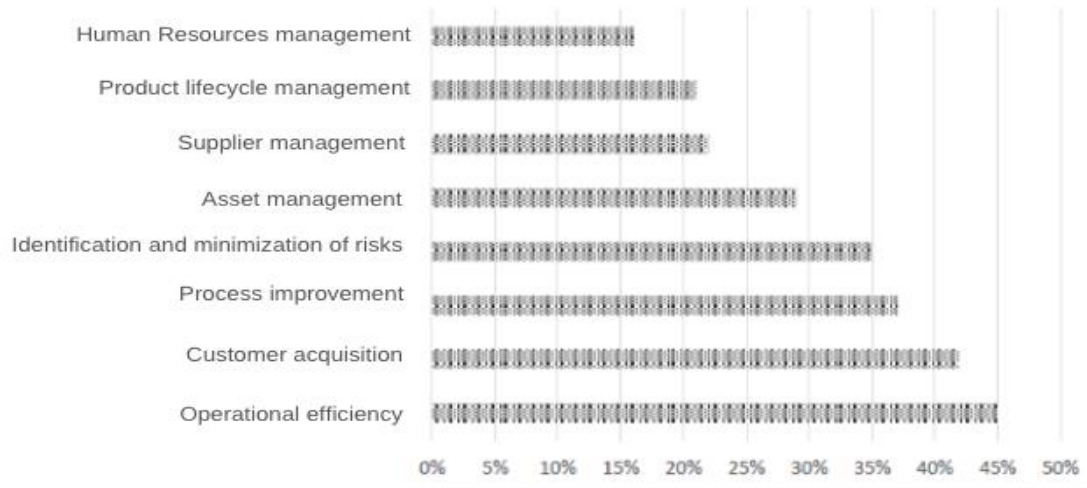

Figure 2. The main areas of use of big data technologies in financial institutions 
Many experts from the financial sphere note that the usage of Big Data technologies in banks gives an essential return in fields connected with improving the operational effectiveness, managing staff of financial institutions, interactions with clients, optimization of business processes and revealing risks.

Among the most significant areas of using Big Data technologies are the following (Thomson Reuters: Big data matured 30 years ago in finance, 2019 \& Big data financial technologies, 2019), (how fintech uses big data, 2019 \& Big data in finance, 2019).

- Increase of the operational effectiveness;

- Improvement of clients' service quality;

- Management of risks and compliance with legal requirements.

Technologies of Big Data provide a higher level of automatization, help to reduce costs, increase of productivity, improvement of interactions with clients, predictability of risks and compliance with legal requirements.

As Big Data technologies improve, banks will master more effective ways to use them to grow their business. With the accumulation of experience in working with available information, banks will open up new opportunities for cooperation with enterprises and institutions in other industries. For example, in retail, it is an opportunity for creating an address and actual consumer offer.(Nikonova et al., 2019)

Selling and exchanging the data will be implemented more comprehensive as other industries find ways of working with clients through their connections with banks. This will open up prospects for generating additional income both for banks and for organizations and companies from other industries.

Priority directions of development and appliance of AI in financial and credit markets are represented in Table 2.

Table 2. Priority directions of AI

\begin{tabular}{ll}
\hline Robotization & $\begin{array}{l}\text { Replacing employees with robots in contact centers to handle customer } \\
\text { requests }\end{array}$ \\
\hline $\begin{array}{l}\text { Combining AI with } \\
\text { robotization of business } \\
\text { processes }\end{array}$ & $\begin{array}{l}\text { Repeating simple repeating actions, recognizing AI texts, determining the } \\
\text { type of documents, extracting significant data, etc. }\end{array}$ \\
\hline $\begin{array}{l}\text { Empowering } \\
\text { products opportunities }\end{array}$ & $\begin{array}{l}\text { Increasing computing capabilities, expanding the functionality of software } \\
\text { products. }\end{array}$ \\
\hline $\begin{array}{l}\text { Service quality } \\
\text { improvement }\end{array}$ & $\begin{array}{l}\text { Collection and analysis of customer information, face recognition } \\
\text { technology, object identification and behavioral analysis. }\end{array}$ \\
\hline
\end{tabular}

The major business consumers of intelligent systems have the following parameters: a large number of different transactions; structured and formalized business processes, complexity and variety of options; high standardization level.

On October 11, 2019, President of Russia Vladimir Putin signed a decree approving the national strategy for the development of artificial intelligence for the period until 2030. The use of artificial intelligence technologies in the economic sphere is "cross-cutting" in nature and contributes to increased efficiency due to:

- Improving the efficiency of planning processes and managerial decision making;

- $\quad$ Automation of repetitive technologies;

- Use of autonomous intelligent equipment and robotic systems, intelligent logistics management systems;

- $\quad$ Increase of security when performing business processes;

- Increase of customer loyalty and satisfaction;

- $\quad$ Optimization of selection and training processes of employees, etc.

\section{Summary}

Nowadays, the banking sector is at a new stage of its development, which is characterized by changes in consumer behavior, technology, and government regulation. One of the most significant trends in modern development is the 
widespread introduction of a digital economy, which leads to an increase in the quantity and quality of services in the banking sector. In such conditions, it becomes necessary to analyze the data that banking organizations have. Previously, traditional databases were used for this, but they have some significant limitations. That is why, at present, banks are increasingly resorting to the use of big data and artificial intelligence technologies.

Artificial intelligence technologies allow banking sector organizations to solve a large number of problems that arise in the process of their activity. These include:

- Countering fraud, including electronic;

- Simplification of planning processes and speed of implementation of some business processes;

- Increasing customer loyalty by improving the quality of banking services, as well as the ability to measure the level of loyalty;

- Acceleration of the process of interaction with customers and contractors.

\section{Conclusion}

All the advantages of introducing information technologies in the financial and credit sector contribute to increased competition between financial institutions and positively affect the entire banking institution as a whole.

Financial institutions are fighting for a client base, improving the quality of customer service, optimizing pricing policies, and introducing ever newer and more convenient digital technologies. The introduction of intelligent technologies is advantageous not only for financial organizations but primarily for their customers. Constant updating of information technologies contributes to the renewal of the financial sector as a whole. Moreover, This spectacular technology is a compound of technologies capable of processing large amounts of data and structuring these data according to various aspects and features. Hence, the merits of this phenomenon in the countries' economies appear beyond question.

\section{Acknowledgments}

The work is performed according to the Russian Government Program of Competitive Growth of Kazan Federal University.

\section{References}

Ahmadi, R., \& Movahed, S. A. H. S. (2019). Study of artificial neural networks in information security risk assessment. Journal of Management and Accounting Studies, 7(02), 1-10.

Artificial Intelligence in the Banking Sector. (2018). IskusstvennyyIntellektVBankovskomSektore "Expert RA". Retrieved September 10, 2018, from https://www.raexpert.ru/researches/banks/bank_ai2018

Big data financial technologies. (2019). Finansovyetechnologiibolshikhdannykh (in Russian). Retrieved September 12, 2019, from https://www.klerk.ru/bank/articles/247931/

Big data in finance. (2019). Bigdatavfinansakh (in Russian). Retrieved September 12, 2019, from https://cyberleninka.ru/article/n/big-data-v-finansah

Bodrov, R. G., Nikonova, T. V., Yusupova, L. M., Kodolova, I. A., \& Pashkeev, A. V. (2018). Analysis of factors affecting modern stock markets. Journal of Social Sciences Research, 2018(5), 250-255.

Evmenov, V. P. (2016). Intelligent control systems: the superiority of artificial intelligence over natural intelligence? (p. 304). Moscow: Librocom.

How FinTech Uses Big Data - Textbook Examples. (2019). KakFinTechispolzuetbolshiedannye-khrestomatiinyeprimery (in Russian). Retrieved September 12, 2019, from https://rb.ru/opinion/big-data-v-fintech/

How FinTech Uses Big Data - Textbook Examples. (2019). KakFinTechispolzuetbolshiedannye-khrestomatiinyeprimery (in Russian). Retrieved September 12, 2019, from https://rb.ru/opinion/big-data-v-fintech/

Kodolova, I. A., Yusupova, L. M., Nikonova, T. V., \& Agliullina, Z. I. (2019). The dynamics of innovation development for enterprises of the Republic of Tatarstan in the conditions of supply chain management and digital economy. International Journal of Supply Chain Management, 8(4), 550-556.

MirgaziyanovnaYusupova, L., Kodolova, I. A., Nikonova, T. V., \& Agliullina, M. I. (2019). Supply chain management in the sphere of household economies in the modern economy of Russia. International Journal of 
Supply Chain Management, 8(4), 538-543.

Neznamov, A. (2018). How to regulate artificial intelligence. Forbes Contributor, (5). Retrieved from https://www.forbes.ru/tehnologii/355757-zakony-robototehniki-kak-regulirovat-iskusstvennyy-intellekt

Nikonova, T. V., Yusupova, L. M., Kodolova, I. A., \& Kalimullina, R. R. (2018). Cluster approach as a factor of increasing the investment attractiveness of the region. Journal of Social Sciences Research, 2018(5), 70-74.

Shal, A. V. (2017). Big Data technologies in Statistics. Uchetistatistika [Accounting and Statistics], 2(46), 18.

The law on artificial intelligence will appear in Russia. (n.d.). ParlamentskayaGazeta (Parliamentary newspaper) VRossiiPoyavitsyaZakonObIskusstvennomIntellekte. Retrieved from http://www.pnp.ru

Thomson Reuters: Big data matured 30 years ago in finance. (2019). ThomsonReuters: Vfinansovoyspherebolshiedannyesozrelieshche30letnazd (in Russian). Retrieved from http://www.cnews.ru/articles/thomson_reuters_v_finansovoj_sfere

Thomson Reuters: Big data matured 30 years ago in finance. (2019). ThomsonReuters: Vfinansovoyspherebolshiedannyesozrelieshche30letnazad (in Russian). Retrieved September 12, 2019 from http://www.cnews.ru/articles/thomson_reuters_v_finansovoj_sfere

Yusupova, L. M., Nikonova, T. V., Kodolova, I. A., \& Kalimullina, R. R. (2018). Modern trends of internet banking market in supply chain of Russia. International Journal of Supply Chain Management, 7(6), 522-527.

\section{Copyrights}

Copyright for this article is retained by the author(s), with first publication rights granted to the journal.

This is an open-access article distributed under the terms and conditions of the Creative Commons Attribution license (http://creativecommons.org/licenses/by/4.0/). 